\title{
MULTI PESTICIDE AND PCB RESIDUES IN NILE CATFISH AND TILAPIA IN ASSIUT CITY, EGYPT
}

\author{
DOHA YAHIA and EMAN E. ELSHARKAWY
}

Department of Forensic Medicine and Toxicology, Faculty of Veterinary Medicine, Assiut University 71526, Assiut, Egypt

\section{ABSTRACT}

Received at: $2 / 6 / 2013$

The current study investigated the levels of multi pesticide residues in the highly consumed types of Nile fish in Egypt; tilapia and cat fish. Total of 50 Nile tilapia (Oreochromis niloticus) and 50 African catfish (Clarias gariepinus) collected from two areas in Assiut city, where most industries are situated beside the agricultural

Accepted: 10/7/2013 activities and raising farm animals are the main activities. The first area; Elwasta, there is a facility of electrical power station, and the second area; Mankbad in which the cement factory is there. Fish samples were analyzed by High Resolution Gas Chromatography/ Mass Spectrometry. Average pesticide residues concentrations \pm $\mathrm{SE}$ in muscle of tilapia and catfish $(\mathrm{n}=10$ pooled samples with five fish each) was determined. The results indicated the presence of different types of organophosphorous (OPs), organochlorine (OCs), polychlorinated biphenyles (PCBs), hexachlorobenzene (HCB) and trifluralin pesticides in Elwasta and Mankbad in varying degrees. Diazenon was the only OP pesticide exceeded the permissible limit in both investigated areas in two types of fish. On the other hand, OCs, PCBs, $\mathrm{HCB}$ and trifluralin pesticide residue levels were not exceeded the maximum allowable concentration limit. As general, an increase in pesticides residue level was obtained in Mankbad than Elwasta. In addition, higher values are realized for the detected pesticide residues in cat fish than tilapia. The results of the study have shown that the extensive and recent use of these types of pesticides in the present time in Egypt

Keywords: Multi pesticide residues; Trifluralin; Cat fish; Tilapia; GC-MS.

\section{INTRODUCTION}

Pesticides play a key role in pest management and preventing human being and domestic animals from infectious diseases. However, it is important to remember that any pesticide should be considered as an active poison (Hogsette et al., 2006). Use of pesticides varies greatly among different parts of the world in types and quantities. Consequently, many international organisations such as the Codex Alimentarius Commission (CAC), WHO/FAO, and European Union (EU) as well as different countries have issued their own pesticide maximum residual limits (MRLs) in the international trade (Lin, 2002).

Pesticides reach aquatic ecosystem by direct application, spray drift, aerial spraying, and erosion, runoff from factories and in sewage. The contamination of water sources is a major source of concern since it is the habitat for fish and other aquatic organisms such as mussels, oysters, prawns and lobsters. Pesticides end up in the tissue of aquatic organisms and bio-accumulates with time (Jiries et al., 2002). Fish consumption could be therefore considered as one of the major sources of human exposure to all environmental contaminants (EFSA, 2005; Storelli, 2008).
Tilapia is the most popular freshwater fish species in Egypt. It plays an important role in fish consumption in Egypt and around the world. The Nile catfish is highly consumed in Egypt because it is cheap and available in most localities. The African catfish tend to live in the turbid and cloudy water. It is exposed to different types of environmental contaminants rather than another fish types. Because of the relatively high fat contents of catfish meat, the fat soluble environmental pollutants such as organochlorine pesticides (OCs) and polychlorinated biphenyls (PCBs) are the more probable pollutants present in catfish meat (Holtan, 1998). Furthermore, the organophosphorus pesticides (OPs) could pollute the tilapia and catfish meat via the recent agricultural application.

OCs pesticides are ubiquitous anthropogenic contaminants that are persistent in the environment, accumulate in fatty tissues and increase in concentration as they move up the food chain (WHO, 1999). Due to their lipophilic nature they accumulate along trophic levels and induce multiple adverse effects in many organisms (Fleming et al., 2006). Although the production and use of many types of OCs have been severely limited in many countries 
including Egypt, they are, nevertheless, still being used unofficially in large quantities in many parts of the world, and in other developing countries because of their effectiveness as pesticides and their relatively low cost (Ntow et al., 2006). Since 1980 DDT and lindane have been officially prohibited from agricultural use in Egypt, and in 1996 a Ministerial Decree prohibited the import and use of 80 pesticides including aldrin, dieldrin, endrin, chlordane, heptachlor, DDT, toxaphene, mirex, lindane, endosulfan, pentachlorophenol, and heptachlor epoxide. Due to the great concern in protecting the human health and environment from POPs, Egypt signed the Stockholm Convention on Persistent Organic Pollutants (POPs) in 2002 and ratified it in 2003 (Baraka et al., 2013). OCs were detected in fresh water fish in previous studies in Egypt by Salah El-Dien and Nasr, (2004), the probable sources of this pesticide group originated from a previous or an illegal use.

Hexachlorobenzene (HCB) was widely used as a pesticide (ATSDR, 2002), and it is still widely distributed in the environment (Barber et al., 2005). Long term oral exposure to $\mathrm{HCB}$ in humans results in a liver disease with associated skin lesions. For the general population exposure to HCB occurs primarily from eating low levels of this organic compound in contaminated food (ATSDR, 2002).

On the other aspect, OPs pesticides are regarded as being low persistent compared with OCs, but some reports have indicated that residues of OPs are persisting for extended period in organic soil and surrounding drainage systems in Egypt by AbdelHalim et al. (2006). Due to their low price and effective ability to control pests, weeds and diseases (He et al., 2009), they had been widely used and became more and more important in agricultural production after OCs were forbidden. OPs residues can concentrate and diffuse by the effect of biological enrichment and food chains; therefore, it might appear in food products and pose a potential risk for human health (Sun et al., 2011).

Polychlorinated biphenyls (PCBs) were commercially produced as complex mixtures containing multiple isomers at different degrees of chlorination. Today PCBs can still be released into the environment from poorly maintained hazardous waste sites that contain PCBs; illegal or improper dumping of PCB wastes; leaks or releases from electrical transformers containing PCBs (ATSDR, 2002). Some PCBs congeners elicit a divers spectrum of toxic and biochemical response including body weigh loss, immunotoxicity (Sormo et al., 2009) and induction of gene expression (El Nemr et al., 2003).

Trifluralin is a selective, preemergence herbicide used to control a wide range of annual grasses and broadleaf weeds. It is toxic to aquatic fish and invertebrates, is typically soil incorporated, is highly absorbent to soil, and essentially non-soluble in water. The potential for bioaccumulation under environment conditions depends largely on the elimination rates in biota and the environment (Han et al., 2007).

Fish consumption is a possible source of pesticides accumulation in humans. It is possible that the accumulation of these contaminants reduces fish quality in the hatchery and undermines their survival after release, resulting in financial costs to aquacultures (Botaro et al., 2011). Therefore, the aim of the present study was to investigate the levels of multi pesticide residues in fish samples including the most famous and highly consumed types of Nile fish in Egypt; to compare the levels of pesticide residues between the two different types of Nile fish (tilapia and catfish) and to compare these levels with the recommended international permissible limits.

\section{MATERIALS and METHODS}

\section{Sampling}

The sampling sites involve two areas in Assiut city, where most industries are situated. The first area; Elwasta, there is a facility of electrical power station, and the second area; Mankbad in which the cement factory is there. The study was included a total of 50 Nile tilapia (Oreochromis niloticus) and 50 African catfish (Clarias gariepinus) collected from the two previous mentioned areas (Elwasta and Mankbad) in Assiut city, Egypt. Two types of fish were investigated for detection and determination of multipesticide residues. Approximately $200 \mathrm{~g}$ from each fish samples were obtained and put into an ice chest. The fish samples were immediately transported to the laboratory in an ice chest with ice and stored at $4{ }^{\circ} \mathrm{C}$ in a refrigerator for two days before extraction and analysis. The fish samples were obtained in a composite manner and placed in clean wide-mouth glassy containers and covered immediately after sampling. Average pesticide residues concentrations $\pm \mathrm{SE}$ in muscle of tilapia $(\mathrm{n}=10$ pooled samples with five fish each) and catfish ( $\mathrm{n}=10$ pooled samples with five fish each) from two different areas in Assiut city, Upper Egypt.

\section{Standards and reagents}

The analytical pesticide standards of the organochlorine pesticides included alachlor, p, p0DDE, lindane, aldrin, heptachlor, dieldrin and hexachlorobenzene (HCB). The organophosphorous analysed in this study were malathion, parathion, methyl parathion, ethion, chlorpyrifos and diazenon, and the herbicide standard is triflurin. Pesticide standards were purchased from Sigma (Poole, UK). The polychlorinated biphenyls (IUPAC Nos. 28, 52, 118 and 138) were from LGC Standards (Teddington, UK). 
Individual stock standard solution of pesticide was prepared by dissolving $10 \mathrm{mg}$ of each compound in $10 \mathrm{~mL}$ hexane and stored in amber bottles. A mixed standard solution was prepared from the individual stock solutions with a concentration of $100 \mathrm{mg} / \mathrm{L}$. A series of calibration standards were prepared by diluting $100 \mathrm{mg} / \mathrm{L}$ of the mixed standard solution to produce a final concentration of $0.1,0.2,0.5,1.0,2.0$ $\mathrm{mg} / \mathrm{L}$ in hexane. Stock and working solutions were stored at $4{ }^{\circ} \mathrm{C}$ and used for no longer than 3 months and 1 week, respectively.

Solvents used were acetone, n-hexane, methylene chloride, toluene and acetonitrile. Anhydrous sodium sulphate and sodium chloride were also used. All the reagents were of analytical (HPLC) grade supplied by $\mathrm{BDH}$, London, UK. Before use; sodium sulphate was heated at $650{ }^{\circ} \mathrm{C}$ for $4 \mathrm{~h}$ and kept in a desiccator. Distilled water was obtained with a Milli-Q system (Millipore, Bedford, MA, USA). For SPE, aminopropyl (NH2) cartridge was purchased from Waters.

\section{Sample extraction}

The extraction and clean up technique employed in this work was according to Chen et al. (2009). Ten grams of previously minced fish sample was placed into a $50 \mathrm{~mL}$ centrifuge tube and mixed with $3.0 \mathrm{~mL}$ water. The mixture was vortexed for $1 \mathrm{~min}$. A $20 \mathrm{~mL}$ aliquot of acetonitrile was added as extraction solvent. The resulting mixture was stirred for $15 \mathrm{~min}$. $5 \mathrm{~g}$ sodium chloride was added to the mixture and vortexed for another $2 \mathrm{~min}$, and then centrifuged for 5 min at $4000 \mathrm{rpm} .10 \mathrm{~mL}$ of the extraction solution was collected in $100 \mathrm{~mL}$ round flask, which was stored in the freezer at $-24{ }^{\circ} \mathrm{C}$ for $20 \mathrm{~min}$ to freeze lipids. Most of the lipids were precipitated as pale yellow, condense lump on the flask surface. Cold extract at $-24{ }^{\circ} \mathrm{C}$ was immediately filtered with filter paper to remove frozen lipids. The precipitated lipid on the flask surface was redissolved in $10 \mathrm{~mL}$ of acetonitrile to perform filtration again by same procedure. The filtered extract was concentrated to 1 $\mathrm{mL}$ by rotary evaporation to follow SPE procedure.

\section{Clean-up by NH2 SPE}

Before sample application, anhydrous sodium sulphate was placed on top of $\mathrm{NH} 2$ cartridge. The cartridge was conditioned with $10 \mathrm{~mL}$ acetonitriletoluene (3:1). When the conditioning solution reached the top of the sodium sulphate, the concentrated extract was added to the cartridge. The flask was rinsed with $2 \mathrm{~mL}$ acetonitrile-toluene (3:1) twice, and the washings were also applied to the cartridge. A reservoir was attached to the cartridge and the pesticides were eluted with $25 \mathrm{~mL}$ acetonitriletoluene $(3: 1)$. The eluate was concentrated to ca 0.5 $\mathrm{mL}$ by rotary evaporation at $40{ }^{\circ} \mathrm{C}$ and then evaporated to dryness with a nitrogen stream. The residue was dissolved in $1 \mathrm{~mL}$ hexane for $\mathrm{GC}-\mathrm{MS}$ analysis.

\section{GC $\backslash$ MS analysis}

The GC used here was Agilent 7890 instrument equipped with 5975 insert ion source mass detection system (Agilent technologies, USA). The analytical capillary column was J\&W Scientific, DB-1701. Column temperature was maintained at $40{ }^{\circ} \mathrm{C}$ for 1 min, and then programmed at $30{ }^{\circ} \mathrm{C} \min ^{-1-}-130{ }^{\circ} \mathrm{C}$, then at $5{ }^{\circ} \mathrm{C} \min ^{-1}-250{ }^{\circ} \mathrm{C}$, and finally at $10^{\circ} \mathrm{C} \mathrm{min}^{-1}-$ $300{ }^{\circ} \mathrm{C}$, which was held for $5 \mathrm{~min}$. Helium, purity $>99.999 \%$, was used as carrier gas at a flow rate of $1.2 \mathrm{~mL} \mathrm{~min}^{-1}$. The injection port temperature was 260 ${ }^{\circ} \mathrm{C}$ and $1 \mathrm{lL}$ samples were injected splitless with the purge on after $1.5 \mathrm{~min}$. The MS ionisation energy was $70 \mathrm{eV}$, the ion-source temperature $230{ }^{\circ} \mathrm{C}$, and the GC-MS interface temperature $280{ }^{\circ} \mathrm{C}$. The selected ion monitoring (SIM) was used and the dwell time of each ion was set at $100 \mathrm{~ms}$. To improve sensitivity, the selected ions used in the SIM mode are divided into fourteen groups, guiding by the individual pesticide retention times. All pesticides were identified by retention time and specific ions, and quantified by the external standard method.

\section{Method validity}

The recovery analysis and the validation of the extraction method were carried out at a fortification average level of $0.02,0.05,0.1 \mathrm{mg} \backslash \mathrm{kg}$, by adding standard solution to untreated fish samples. Samples were allowed to equilibrate for $30 \mathrm{~min}$ prior to extraction, and were processed according to procedure described above. The recovery assays were replicated five times. All samples were treated and analysed using GC-MS-SIM mode described above. These analyses were carried out at the analytical chemistry unit (ACAL) of Pesticide Residue Laboratory in Assiut University, Egypt.

\section{Statistical analyses}

A value of zero was assigned for results below the limit of detection. The Kolmogorov-Smirnov Test was used to verify that all data was normally distributed. Data were expressed as Mean $\pm \mathrm{SE}$, Statistical analysis was conducted using SPSS 16.0 for windows (SPSS, Chicago, USA). Results were considered significant at a $5 \%$ level $(\mathrm{p}<0.05)$.

\section{RESULTS}

The validation analysis gave an average of $65 \%$ extraction efficiency and an average reproducibility of $93 \%$ indicating that the analytical process was efficient. Table1 shows some parameters for determination of pesticide residues in fish tissue by Agilent 7890 GC-MS. 
Assiut Vet. Med. J. Vol. 59 No. 138 July 2013

Table 1: Parameters for determination of pesticide residues in fish tissue (fresh matter) by GC-MS.

\begin{tabular}{|c|c|c|c|c|}
\hline Pesticides & $\begin{array}{l}\text { Retention time } \\
\qquad(\min )\end{array}$ & $\begin{array}{l}\text { Group/start time } \\
\text { (number/min) }\end{array}$ & $\begin{array}{c}\text { LOD } \\
\left(\mu \mathrm{kg}^{-1}\right)\end{array}$ & $\begin{array}{l}\text { Target ion (qualifier } \\
\quad \text { ion) }(\mathbf{m} / \mathbf{z})\end{array}$ \\
\hline Trifluralin & 10.12 & $\mathbf{I} / 10$ & 1.0 & 306 \\
\hline $\mathrm{HCB}$ & 10.14 & & 1.0 & 284 \\
\hline Lindan & 10.75 & & 2.5 & 227 \\
\hline Diazenon & 10.87 & & 5.7 & 304 \\
\hline PCB28 & 12.16 & II $/ 12$ & 2.0 & 256 \\
\hline Alachlor & 12.32 & & 5.5 & 188 \\
\hline Parathion & 12.36 & & 6.7 & 291 \\
\hline Heptachlor & 12.53 & & 5.7 & 272 \\
\hline PCB 52 & 13.09 & III/13 & 2.0 & 290 \\
\hline Malathion & 13.26 & & 6.1 & 173 \\
\hline Aldrin & 13.55 & & 2.5 & 263 \\
\hline $\mathrm{p}, \mathrm{pDDE}$ & 16.85 & IV/16 & 1.0 & 246 \\
\hline Dieldrin & 16.97 & & 10 & 263 \\
\hline PCB 118 & 18.09 & V/18 & 2.0 & 326 \\
\hline Ethion & 18.44 & & 1.3 & 231 \\
\hline PCB 138 & 19.90 & & 2.0 & 360 \\
\hline Chlorpyrifos & 23.32 & & 6.7 & 314 \\
\hline
\end{tabular}

\section{Cat fish in area 1}

The OP detection includes chloropyrifos, diazenon and malathion while the parathion methyl and ethion not detected. The mean values of these pesticides were $0.34 \pm 0.06,6.46 \pm 0.48$ and $0.19 \pm 0.01 \mathrm{ppb}$, respectively Table (2). In comparison with the MRL diazenon only exceed the permissible limit, where its level reached to $6.46 \pm 0.48 \mathrm{ppb}$ while its permissible limit is 2 ppb according to US.EPA, (1991) Table (4). The OC pesticides detect only lindan and p,pDDE in mean values of $0.29 \pm 0.08$ and $1.83 \pm 0.40 \mathrm{ppb}$, respectively Table (2). These levels not exceed the MRL of lindan (200ppb) according to CAC, (2009) or MRL of DDT pesticides according to permissible limit set by US EPA, 1991 (20 ppb) and EU, (2011) (100 ppb) Table (5). The PCB congeners 28 and 52 could be detected in cat fish in areal in the mean values of $0.21 \pm 0.02$ and $0.05 \pm 0.01 \mathrm{ppb}$, respectively Table (2). These levels were not exceeded the maximum allowable concentration of $2000 \mathrm{ng} / \mathrm{g}$ proposed by Food and Drug Administration, USA (US.FDA, 2001). HCB fungicide and Trifluralin herbicide were detected in cat fish in this area in the mean values of $0.92 \pm 0.14$ and $0.06 \pm 0.02 \mathrm{ppb}$, respectively. These limits were not exceeded the permissible limit according to EU, (2011) Table (6).

\section{Cat fish in area 2}

Chlorpyrifos, diazenon, malathion and ethion were the OP pesticides which detected in area 2 in cat fish. Their mean values were $0.82 \pm 0.01,2.60 \pm 0.47,0.62$ \pm 0.06 and $0.36 \pm 0.05 \mathrm{ppb}$, respectively Table (3). In comparison with MRL diazenon only exceeded the permissible limit according to US.EPA, (1991) Table (4). OC pesticides alachlor, lindan, ppDDE, dieldrin and heptachlor were detected in the mean values of $0.24 \pm 0.01,1.66 \pm 0.22,0.81 \pm 0.05,0.93 \pm 0.14$ and $0.41 \pm 0.05$, respectively Table (3). In comparison with the MRL of these pesticides, all these pesticide residue levels were below the MRL values (US.EPA, 1983 and 1991) Table (5). The PCB congeners 52, 138 and 118 can be detected in cat fish in area2 in the mean values of $0.90 \pm 0.05,0.60 \pm 0.05$ and $0.70 \pm$ $0.05 \mathrm{ppb}$, respectively Table (3). These levels were not exceeded the maximum allowable concentration of $2000 \mathrm{ppb}$ proposed by Food and Drug Administration, USA (USFDA, 2001). Trifluralin herbicide was detected in a value of $1.45 \pm 0.12 \mathrm{ppb}$. This level is lower than the permissible limit 
according to EU, (2011). HCB fungicide was not detected in cat fish in this area Table (6).

\section{Tilapia in area 1}

Diazenon, malathion, parathion and ethion are the OP pesticides that could be detected in tilapia in area 1 . Their mean values are $2.27 \pm 0.49,0.54 \pm 0.14,6.38$ \pm 0.96 and $4.80 \pm 1.23 \mathrm{ppb}$, respectively whether, chlorpyrifos cannot be detected Table (2). Diazenon and parathion levels have been exceeded the permissible limit (2ppb) proposed by (US.EPA, 1991) Table (4). Lindan, p,pDDE and aldrin OC pesticides were detected in tilapia in area 1 . The mean values are $0.89 \pm 0.11,1.25 \pm 0.34$ and $0.61 \pm 0.23 \mathrm{ppb}$, respectively Table (2). These limits were not exceed the maximum allowable concentration has been established by US.EPA, (1991); EU, (2011) and CAC, (2009) in the levels of 20, 200 and $300 \mathrm{ppb}$, respectively Table (5). The different congeners of PCBs were detected in tilapia in this area including congeners 28 and 52 in the mean values of $0.24 \pm$ 0.08 and $0.75 \pm 0.65 \mathrm{ppb}$, respectively. These limits are not exceeded the permissible limit had been set by (US.FDA, 2007). In tilapia in area 1 , we can also detect HCB fungicide and Trifluralin herbicide in the mean values of $0.58 \pm 0.37$ and $0.06 \pm 0.02 \mathrm{ppb}$, respectively Table (2). These values were lower than the permissible limits proposed by EU, (2011) Table (6).

\section{Tilapia in area 2}

In the present study, the OP pesticides were detected in tilapia fish in area 2 including diazenon and methyl parathion in the mean values of $2.04 \pm 0.56$ and 18.50 $\pm 0.62 \mathrm{ppb}$, respectively Table (3). These values were higher than the permissible limit had been set by (US.EPA, 1991) Table (4). Both of chlorpyrifos and malathion were not be detected in this area in tilapia. Lindan, alderin and heptachlor were detected as OC pesticides in tilapia in this area. Their values were $0.47 \pm 0.05,0.22 \pm 0.03$ and $0.18 \pm 0.01 \mathrm{ppb}$, respectively Table (3). These values were not exceeded the permissible limit had been established by EU, (2011) and CAC, (2009) Table (5). PCBs 28 and 52 could be detected in the values of $0.30 \pm 0.01$ and $0.61 \pm 0.31 \mathrm{ppb}$, respectively Table (3). In comparison with the maximum residue limit of these pesticides, these PCBs congener's residue levels were below the MRL values according to US.FDA (2007). HCB fungicide and Trifluralin herbicide were detected in this area in the mean values of $3.06 \pm 0.01$ and $0.14 \pm 0.01 \mathrm{ppb}$, respectively. These values were lower the permissible limits proposed by EU, (2011) Table (6).

Table 2: Concentrations $((\mu \mathrm{g} / \mathrm{Kg}))$ of the different types of pesticide residues in the examined catfish and tilapia samples $(n=10$ pooled samples with five fish each). In area 1 (Elwasta).

\begin{tabular}{|c|c|c|c|c|}
\hline \multirow[t]{3}{*}{ Pesticides } & \multicolumn{4}{|c|}{ Type of fish } \\
\hline & \multicolumn{2}{|c|}{ Cat fish } & \multicolumn{2}{|c|}{ Tilapia fish } \\
\hline & $\begin{array}{c}\text { Concentration } \\
\text { range } \\
(\mu \mathrm{g} / \mathrm{Kg})\end{array}$ & $\begin{array}{c}\text { Average } \\
\text { concentration } \\
(\mu \mathrm{g} / \mathrm{Kg})\end{array}$ & $\begin{array}{c}\text { Concentration range } \\
(\mu \mathrm{g} / \mathrm{Kg})\end{array}$ & $\begin{array}{c}\text { Average } \\
\text { concentration } \\
(\mu \mathrm{g} / \mathrm{Kg})\end{array}$ \\
\hline Chlorpyrifos & $0.22-0.42$ & $0.34 \pm 0.06$ & $\mathrm{ND}$ & ND \\
\hline Diazenon & $5.561-7.21$ & $6.46 \pm 0.48$ & $0.8-3.88$ & $2.27 \pm 0.49$ \\
\hline Malathion & $0.18-0.21$ & $0.19 \pm 0.01$ & $0.23-0.91$ & $0.54 \pm 0.14$ \\
\hline Parathion & $\mathrm{ND}$ & ND & $4.64-7.98$ & $6.38 \pm 0.96$ \\
\hline Ethion & $\mathrm{ND}$ & ND & $2.37-6.373$ & $4.80 \pm 1.23$ \\
\hline Lindan & $0.13-0.42$ & $0.29 \pm 0.08$ & $0.67-1.08$ & $0.89 \pm 0.11$ \\
\hline $\mathrm{p}, \mathrm{pDDE}$ & $1.11-2.5$ & $1.83 \pm 0.40$ & $0.65-1.832$ & $1.25 \pm 0.34$ \\
\hline Aldrin & ND & ND & $0.16-0.963$ & $0.61 \pm 0.23$ \\
\hline PCB28 & $0.18-0.26$ & $0.21 \pm 0.02$ & $0.14-0.41$ & $0.24 \pm 0.08$ \\
\hline PCB 52 & $0.05-0.06$ & $0.05 \pm 0.01$ & $0.03-2.062$ & $0.75 \pm 0.65$ \\
\hline HCB & $0.73-1.20$ & $0.92 \pm 0.14$ & $0.2-1.34$ & $0.58 \pm 0.37$ \\
\hline Trifluralin & $0.03-0.08$ & $0.06 \pm 0.02$ & $0.02-0.10$ & $0.06 \pm 0.02$ \\
\hline
\end{tabular}

ND: not detected, Underline: exceeded the MRL. 
Table 3: Concentrations $((\mu \mathrm{g} / \mathrm{Kg}))$ of the different types of pesticide residues in the examined catfish and tilapia samples $(n=10$ pooled samples with five fish each). In area 2 (Mankabad).

\begin{tabular}{|c|c|c|c|c|}
\hline \multirow[t]{3}{*}{ Pesticides } & \multicolumn{4}{|c|}{ Type of fish } \\
\hline & \multicolumn{2}{|r|}{ Cat fish } & \multicolumn{2}{|c|}{ Tilapia fish } \\
\hline & $\begin{array}{c}\text { Concentration } \\
\text { range } \\
(\mu \mathrm{g} / \mathrm{Kg})\end{array}$ & $\begin{array}{c}\text { Average concentration } \\
(\mu \mathrm{g} / \mathrm{Kg})\end{array}$ & $\begin{array}{c}\text { Concentration } \\
\text { range } \\
(\mu \mathrm{g} / \mathrm{Kg})\end{array}$ & $\begin{array}{c}\text { Average concentration } \\
(\mu \mathrm{g} / \mathrm{Kg})\end{array}$ \\
\hline Chlorpyrifos & $0.80-0.83$ & $0.82 \pm 0.01$ & ND & $\mathrm{ND}$ \\
\hline Diazenon & $1.9-3.5$ & $2.6 \pm 0.47$ & $0.46-2.17$ & $1.04 \pm 0.56$ \\
\hline Malathion & $0.5-0.7$ & $0.62 \pm 0.06$ & ND & $\mathrm{ND}$ \\
\hline $\begin{array}{l}\text { Methyl } \\
\text { parathion }\end{array}$ & $\overline{\mathrm{ND}}$ & $\mathrm{ND}$ & $17.60-19.70$ & $18.50 \pm 0.62$ \\
\hline Ethion & $0.25-0.45$ & $0.36 \pm 0.05$ & ND & ND \\
\hline Alachlor & $0.23-0.25$ & $0.24 \pm 0.01$ & ND & $\mathrm{ND}$ \\
\hline Lindan & $1.38-2.10$ & $1.66 \pm 0.22$ & $0.41-0.57$ & $0.47 \pm 0.05$ \\
\hline $\begin{array}{l}\text { P,pDDE } \\
\end{array}$ & $0.70-0.90$ & $0.81 \pm 0.05$ & ND & $\mathrm{ND}$ \\
\hline Dieldrin & $0.72-1.20$ & $0.93 \pm 0.14$ & ND & $\overline{\mathrm{ND}}$ \\
\hline Alderin & ND & $\mathrm{ND}$ & $0.17-0.28$ & $0.22 \pm 0.03$ \\
\hline Heptachlor & $0.30-0.50$ & $0.41 \pm 0.05$ & $0.18-0.19$ & $0.18 \pm 0.01$ \\
\hline PCB28 & ND & ND & $0.29-0.31$ & $0.30 \pm 0.01$ \\
\hline $\begin{array}{l}\text { PCB } 52 \\
\end{array}$ & $0.80-1$ & $0.90 \pm 0.05$ & $0.30-1.22$ & $0.61 \pm 0.31$ \\
\hline PCB 138 & $0.50-70$ & $0.60 \pm 0.05$ & ND & $\mathrm{ND}$ \\
\hline PCB 118 & $0.60-0.80$ & $0.70 \pm 0.05$ & ND & $\mathrm{ND}$ \\
\hline $\mathrm{HCB}$ & ND & ND & $3.04-3.10$ & $3.06 \pm 0.01$ \\
\hline Trifluralin & $0.12-0.16$ & $1.45 \pm 0.12$ & $1.25-1.67$ & $0.14 \pm 0.01$ \\
\hline
\end{tabular}

ND: not detected, Underline: exceeded the MRL.

Table 4: Frequency distribution of the organo phosphorous pesticide residues in the examined catfish and tilapia compared with the recommended permissible limits (P.L.). $\mathrm{N}=10$ pooled samples with five fish each.

\begin{tabular}{|c|c|c|c|c|c|c|c|c|c|c|c|c|c|}
\hline \multirow{3}{*}{$\begin{array}{c}\text { Residues of } \\
\text { Organophosph- } \\
\text { orous } \\
\text { Pesticide }\end{array}$} & \multirow{3}{*}{$\begin{array}{c}\text { Permissible } \\
\text { limits } \\
(\mu \mathrm{g} / \mathrm{Kg})\end{array}$} & \multicolumn{4}{|c|}{ Not Detected } & \multicolumn{4}{|c|}{ Within P.L. } & \multicolumn{4}{|c|}{ Exceeded P.L. } \\
\hline & & \multicolumn{2}{|c|}{ Area1 } & \multicolumn{2}{|c|}{ Area2 } & \multicolumn{2}{|c|}{ Areal } & \multicolumn{2}{|c|}{ Area2 } & \multicolumn{2}{|c|}{ Areal } & \multicolumn{2}{|c|}{ Area2 } \\
\hline & & Cat & Tilap & Cat & Tilap & Cat & Tilap & Cat & Tilap & Cat & Tilap & Cat & Tilap \\
\hline Malathion & $20^{(I)}$ & & & & & WP & WP & WP & WP & & & & \\
\hline Parathion & $2^{(2)}$ & ND & & & & & & WP & WP & & EX & & \\
\hline Ethion & $10^{(l)}$ & $\mathrm{ND}$ & & & & & WP & WP & WP & & & & \\
\hline Chlorpyrifos & $10^{(2)}$ & & ND & & ND & WP & & WP & & & & & \\
\hline Diazenon & $2^{(2)}$ & & & & & & & & & EX & EX & EX & EX \\
\hline $\begin{array}{l}\text { Methyl } \\
\text { parathion }\end{array}$ & $2^{(2)}$ & ND & ND & & & & & WP & & & & & EX \\
\hline
\end{tabular}

ND: not detected. WP: within permissible limit. EX: exceeded permissible limit.

${ }^{(1)}$ EU, $2011^{(2)}$ US. EPA, 1991 
Table 5: Frequency distribution of the organochlorine pesticide residues in the examined catfish and tilapia compared with the recommended permissible limits (P.L.). $\mathrm{N}=10$ pooled samples with five fish each.

\begin{tabular}{|c|c|c|c|c|c|c|c|c|c|c|c|}
\hline \multirow{3}{*}{$\begin{array}{l}\text { Residues of } \\
\text { Organochlorine } \\
\text { Pesticides }\end{array}$} & \multirow{3}{*}{$\begin{array}{c}\text { Permissible } \\
\text { limits } \\
(\mu \mathrm{g} / \mathrm{Kg})\end{array}$} & \multicolumn{4}{|c|}{ Not Detected } & \multicolumn{4}{|c|}{ Within P.L. } & \multicolumn{2}{|c|}{ Exceeded P.L. } \\
\hline & & \multicolumn{2}{|c|}{ Areal } & \multicolumn{2}{|c|}{ Area2 } & \multicolumn{2}{|c|}{ Areal } & \multicolumn{2}{|c|}{ Area2 } & Area1 & Area2 \\
\hline & & Cat & Tilap & Cat & Tilap & Cat & Tilap & Cat & Tilap & Cat Tilap & Cat Tilap \\
\hline Heptachlor & $200^{(1)}$ & & & & & WP & WP & WP & WP & & \\
\hline Alachlor & $20^{(I)}$ & & & & $\mathrm{ND}$ & WP & WP & WP & & & \\
\hline Lindan & $200^{(1)}$ & & & & & WP & WP & WP & WP & & \\
\hline $\mathrm{p}, \mathrm{pDDE}$ & $\begin{array}{l}100^{(2)} \\
20^{(3)}\end{array}$ & & & & ND & WP & WP & WP & & & \\
\hline Alderin & $300^{(1)}$ & $\mathrm{ND}$ & & ND & & & WP & & WP & & \\
\hline Dieldrin & $300^{(1)}$ & & & & $\mathrm{ND}$ & WP & $\mathrm{WP}$ & WP & & & \\
\hline
\end{tabular}

ND: not detected. WP: within permissible limit. EX: exceeded permissible limit.

(1) $\mathrm{CAC}, 2009{ }^{(2)}$ EU, $2011^{(3)}$ US. EPA, 1991

Table 6: Frequency distribution of the polychlorinated biphenyl pesticide residues in the examined catfish compared with the recommended permissible limits (P.L.). $\mathrm{N}=10$ pooled samples with five fish each.

\begin{tabular}{|c|c|c|c|c|c|c|c|c|c|c|c|}
\hline \multirow{3}{*}{$\begin{array}{c}\text { Residues of } \\
\text { Polychlorinated } \\
\text { biphenyl } \\
\text { Pesticides }\end{array}$} & \multirow{3}{*}{$\begin{array}{c}\text { Permissible } \\
\text { limits } \\
(\mu \mathrm{g} / \mathrm{Kg})\end{array}$} & \multicolumn{4}{|c|}{ Not Detected } & \multicolumn{4}{|c|}{ Within P.L. } & \multicolumn{2}{|c|}{ Exceeded P.L. } \\
\hline & & \multicolumn{2}{|c|}{ Area1 } & \multicolumn{2}{|c|}{ Area2 } & \multicolumn{2}{|c|}{ Areal } & \multicolumn{2}{|c|}{ Area2 } & Area1 & Area2 \\
\hline & & Cat & Tilap & Cat & Tilap & Cat & Tilap & Cat & Tilap & Cat Tilap & Cat Tilap \\
\hline PCB28 & $2000^{(1)}$ & & & ND & & WP & WP & & WP & & \\
\hline PCB 52 & $2000^{(l)}$ & & & & & WP & WP & WP & WP & & \\
\hline PCB118 & $2000^{(l)}$ & ND & ND & & ND & & & WP & & & \\
\hline PCB138 & $2000^{(1)}$ & ND & ND & & ND & & & WP & & & \\
\hline $\mathrm{HCB}$ & $200^{(2)}$ & & & ND & & WP & WP & & WP & & \\
\hline Trifluralin & $10^{(2)}$ & & & & & WP & WP & WP & WP & & \\
\hline
\end{tabular}

ND: not detected. WP: within permissible limit. EX: exceeded permissible limit.

${ }^{(1)}$ U.S.F.D.A., $2007^{(2)}$ EU, 2011

\section{Comparison between cat fish and tilapia in same area}

In areal (Elwasta), the pesticides could be detected in both cat fish and tilapia were diazenon, malathion, DDE, lindane, PCB 28, 52, HCB and trifluralin. Diazinon, HCB and DDE levels were higher in cat fish than tilapia, while lindane, malathion and PCB 52 levels were higher in tilapia than cat fish Fig (1). In area 2 (Mankabad), the pesticides could be detected in both cat fish and tilapia were diazenon, lindane, heptachlor, PCB 52 and trifluralin. All detected pesticides levels were higher in cat fish than tilapia in this area Fig (2). 


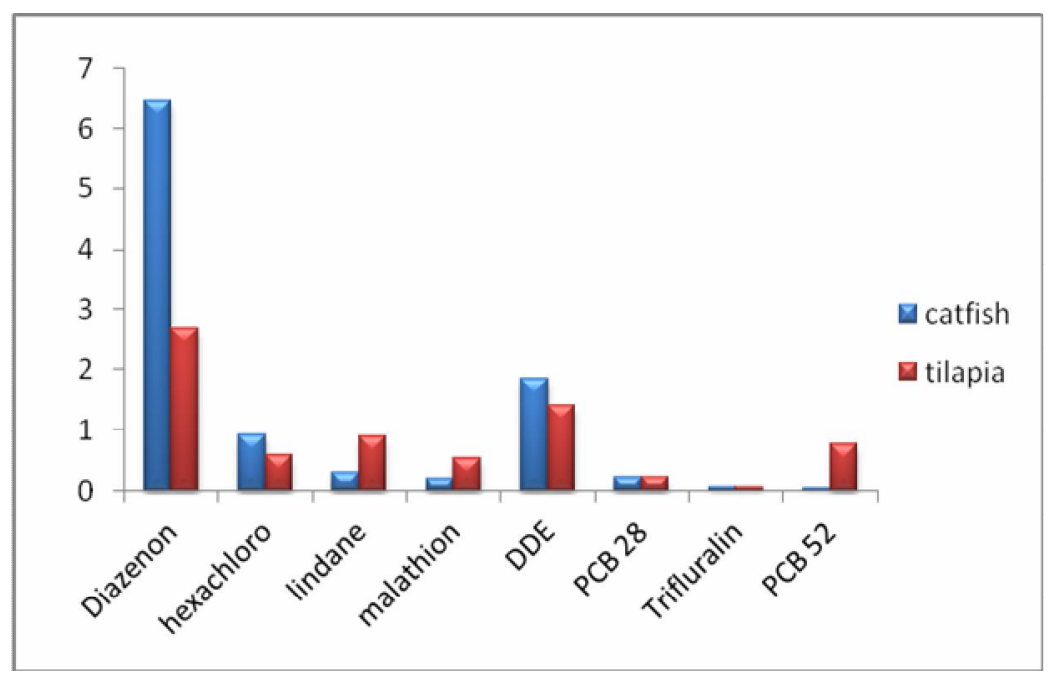

Fig.1: Comparison between the pesticide residues levels $(\mu \mathrm{g} / \mathrm{Kg})$ in cat fish and tilapia in Elwasta (area1).

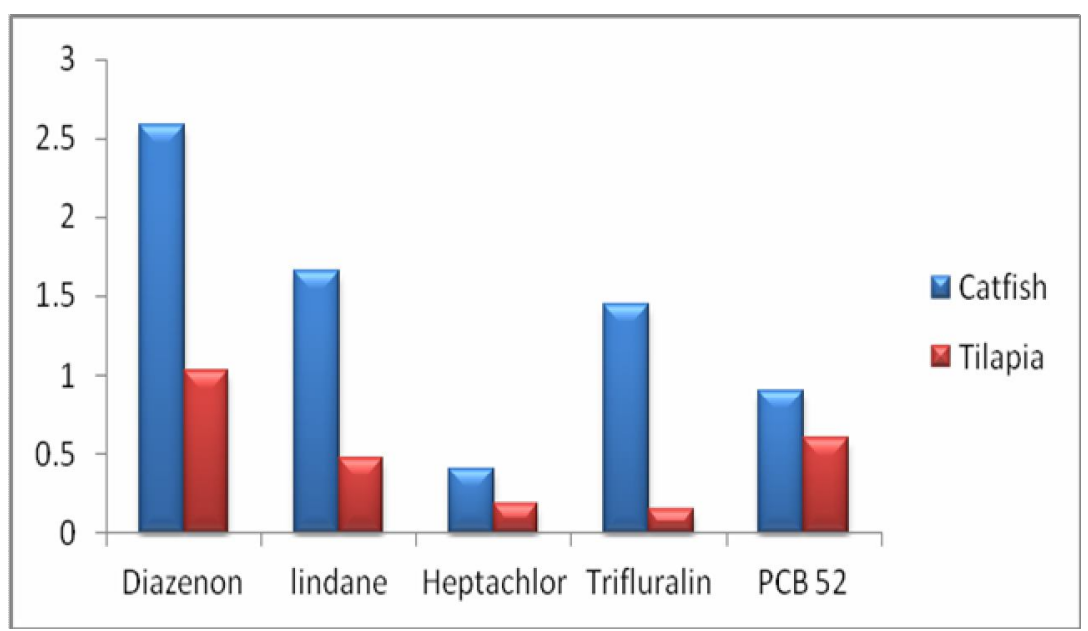

Fig.2: Comparison between the pesticide residues levels $(\mu \mathrm{g} / \mathrm{Kg})$ in cat fish and tilapia in Mankabad $(\operatorname{area} 2)$.

\section{Comparison between area 1 and area 2}

Fig (3) shows diazenon level was higher in area 1 than in area 2. Lindane, trifluralin and PCB 52 levels were higher in area 2 than area1.

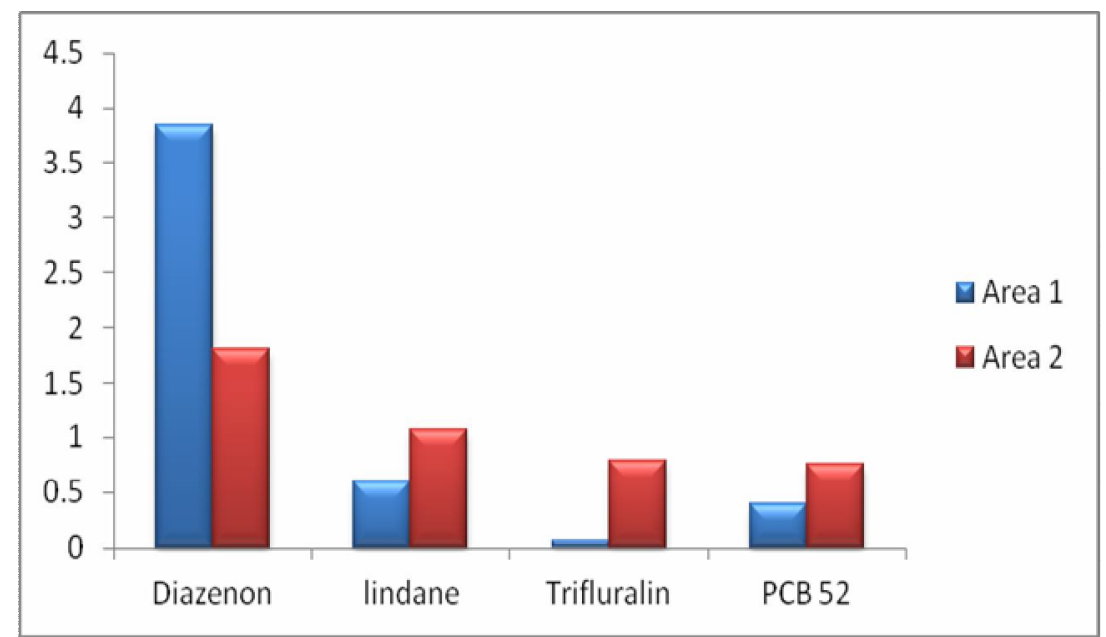

Fig.3: Comparison between the pesticide residues levels $(\mu \mathrm{g} / \mathrm{Kg})$ in Elwasta (area1) and Mankbad (area2). 


\section{DISCUSSION}

In recent times, the extent of the use of pesticides, and their mode of application including their abuse especially in agriculture have been of much concern to environmental scientists. Alongside their uses are also the residual effect of these pesticides and particularly their replicating effect on human health (Hurst et al., 1991). In the present study, the OP pesticides could be detected in cat fish were chloropyrifos, diazenone and malathion in area 1, chlorpyrifos, diazenon, malathion and ethion in area2. In tilapia, diazenon, malathion, parathion and ethion were the OP pesticides could be detected in area 1, while diazenon and parathion were OP pesticide could be detected in area2. Diaznon was the only OP pesticide exceeded the permissible limit in both investigated areas in two types of fish, where its level reaches to $6.46 \pm 0.48$ and $2.27 \pm 0.49 \mathrm{ppb}$ in cat fish and tilapia, respectively, while its permissible limit is 2 ppb according to USEPA, (1991). In another study by Salah El- Dien and Mahmoud, (2011), they could not detect any OP pesticides in cat fish collected from the Zagazig and Abo Kabeer district markets in Sharkia Governorate, Egypt. However, in Ghana lagoons, Essumang et al. (2009) detected OP pesticides chlorpyrifos and diazenon in fish samples. However, these pesticides residues levels were below the levels obtained in our study, in which they ranged between $0.0001-0.0003 \mathrm{mg} / \mathrm{kg}$.

In cat fish the OC pesticides that could be detected were lindan and p,pDDE in area1, while alachlor, lindan, ppDDE, dieldrin and heptachlor were detected in area 2. Lindan, p,pDDE and aldrin were the OC pesticides were detected in tilapia in area 1 , and lindan, alderin and heptachlor were detected as OC pesticides in tilapia in area 2 .

All OC pesticide residue levels were below the MRL values (US.EPA, 1983 and 1991). In previous study by Salah El- Dien and Mahmoud, (2011), they detected some OC pesticides as $30 \%$ for $\alpha \mathrm{BHC}$ and $76.66 \%$ for aldrin + dieldrin in cat fish. But their values were higher than levels obtained in our study. On the other hand, Essumang et al. (2009) detected some OC pesticides as DDE, DDD and p,p'-DDT in fish samples in Ghana. These pesticides residues levels were below the levels obtained in our study, in which they ranged between $0.0030-0.1000 \mathrm{mg} / \mathrm{kg}$. Similarly to our result, previous studies with wild tilapia have found that DDE is the most predominant RDDT metabolite in fish muscle (Kairu, 1999; Manirakiza et al., 2002; Mwevura et al., 2002; Sapozhnikova et al., 2004; Darko et al., 2008). In the present study, p.p -DDE was the predominant metabolite found in cat fish and tilapia. However, these studies reported lower DDE levels in wild tilapia than the Nile tilapia analyzed in this study, which ranged from 0.017 to $0.585 \mathrm{ug} / \mathrm{kg}$. While the levels of tilapia our research ranged from 0.65 to $1.832 \mathrm{ug} / \mathrm{kg}$. DDT and its metabolites had the highest residue levels of $\mathrm{OC}$ pesticides in fish samples from the Nile River and coastal lakes of Egypt. The reported levels of DDT residues in T. nilotica and catfish collected in 1986 and 1991 from local markets were found to exceed the low end of the MRL in most samples (Dogheim et al., 1990, 1996). While more recent studies reported data for different fish species (Mugil, T. nilotica and C. lazero) from the River Nile and Delta lakes showing lower concentrations, which were below the low end of the maximum residue limits (MRLs) (Aly and Badawy, 1984; Badawy and El-Dib, 1984; El Nabawi et al., 1987; Abou-Donia, 1990; Abd-Allah et al., 1990; UNEP, 1992). At all locations, p,p -DDE was the predominant isomer (Abd-Allah et al., 1998). Regarding to DDT metabolites in our study, DDE accounted for almost $100 \%$ of the DDTs, which is not surprising, as its incorporation into fish tissues usually involves altering the form of the residual metabolite and is due to the lesser half-life of p,p0DDT ( 8 months) when compared to p,p0-DDE (7 years) in fish (Binelli and Provini, 2003). Also, the uptake of DDE from the environment, rather than DDT, indicates that no substantial fresh input of DDT has occurred in these sites. The recent studies indicated a decline in residue levels in the Nile River and coastal lakes, reflecting the effectiveness of the restrictions imposed on the DDT and lindane use since mid-1980s. In Brazil, D' Amato et al. (2007) investigated DDT concentrations and its metabolites in some fish species collected in the Amazon area in two periods, between 1991 and 1996 and in 2002. In the first period, concentrations up to $150.3 \mathrm{ng} / \mathrm{g}$ (ww) were observed, markedly higher than values found in 2002 , in which the average DDT levels were of 8.9 ng g/1. p,p0-DDT was the predominant metabolite found in 1991 and, 10 years later, higher concentrations of DDE were observed. The authors associated this fact to an increase in the biotransformation of p,p 0-DDT, as well as a decline in the use of commercial products containing this substance.

In our study, the other detected OCs as lindan, alderine, dielderin and heptachlor present in various concentration range in cat fish and tilapia. In Egypt, a limited monitoring program conducted during 19851986 showed that aldrin, dieldrin, endrin and heptachlor, and its epoxide were among the residues detected most often in bolti fish and catfish samples collected from Beni-Suef and Fayoum governorates (Dogheim et al., 1988, 1990). In contrary to our results, the low end of the maximum range limit was exceeded in all samples, whereas mean levels for endrin and heptachlor were reported to be 219 and 398 ng/g ww, respectively (Dogheim et al., 1996). In a later study, aldrin and dieldrin were not detected in fish samples collected in 1992 from the local Egyptian markets in Cairo. Also, aldrin, dieldrin, 
endrin and heptachlor were not detected in fish samples collected from Kafr El Zayat in 1994 (Dogheim et al., 1996). In the Nile River and Manzala Lake, the concentrations of heptachlor were reported in the range $0.07-0.16 \mathrm{ng} / \mathrm{g}$ ww (Yamashita et al., 2000).

Our results revealed that the PCB congeners 28 and 52 could be detected in cat fish in area 1 and the PCB congeners 52, 118 and138 could be detected in cat fish in area 2. In tilapia, the PCB congeners 28 and 52 could be detected in area 1 and 2 . These levels were not exceeded the maximum allowable concentration of $2000 \mathrm{ng} / \mathrm{g}$ proposed by Food and Drug Administration, USA (US.FDA, 2001). It should be mentioned that no maximum levels for non dioxin like (ndl) PCB in feed and food have been set in the European Union, so far. According to Commission Regulation (EC) No. 199/2006 (199/ 2006 EC, 2006), maximal levels based on cumulative risk assessment and relative toxicity regarding 2, 3, 7, 8-TCDD, have been given only for dioxin like (dl) PCBs. The maximum level of $100 \mathrm{ng} / \mathrm{g}$ fresh weight for the sum of six ndl PCBs in fish has been proposed by the European Commission (EC) draft regulation (AFSSA, 2007). It can be seen from the Table 6 that mean concentration of ndl PCBs is far from European draft maximum level (Jankovic et al., 2008, 2010). According to EFSA document (EFSA, 2005) more than $90 \%$ of the ndl PCBs exposure in the general population is via food. In Egypt, PCBs were the second most predominant contaminants occurring in fish samples indicating that they are ubiquitous contaminants in the coastal marine environment of Egypt. High concentrations in the range 180-227 ng/g ww (reported as Aroclor 1248) and 26-90 ng/g ww (56 congeners) were found in fish samples from El-Max (Abd-Allah and Ali, 1994) and Abu-Quir (El Nabawi et al., 1987), respectively. Aroclor 1248 levels were reported in the range $17-31 \mathrm{ng} / \mathrm{g}$ ww in fish (M. cephalus) and 19-46 ng/g ww in bivalves (Donax sp.) from coastal areas in Egypt (Abd-Allah et al., 1998). A reference dose of $20 \mathrm{ng} / \mathrm{kg}$ b.w./d for all 209 PCB congeners was proposed by WHO (IPCS/WHO CICAD, 2003). This reference dose, expressed as a tolerable daily intake (TDI) was adopted by the French Agency for Food Safety (AFSSA) in 2003 and 2007 (AFSSA, 2007; Baars et al., 2004). In addition, since the sum of six PCB congeners most commonly found in food matrices (PCB-28, 52, 101, 138, 153, and 180) accounts for approximately $50 \%$ of total ndl PCBs, a "guidance value", of $10 \mathrm{ng} / \mathrm{kg}$ b.w./day could be proposed for this group of six congeners (Arnich et al., 2009).

$\mathrm{HCB}$ fungicide and trifluralin herbicide were detected in cat fish in areal but trifluralin only was detected in cat fish in area 2. In tilapia, hexachlorobenzine and trifluralin could be detected in both areas. These levels were lower the permissible limit according to EU, (2011). The lower concentration levels for HCB were obtained in this study in comparison with those of previous investigations since the average obtained range of $\mathrm{HCB}$ residues level was 0.92 to $3.06 \mathrm{ppb}$. However, the reported levels of HCB in fish species collected from different coastal areas in Egypt during the $1980 \mathrm{~s}$ and $1990 \mathrm{~s}$ was in the range $0.25-8.5 \mathrm{ng} / \mathrm{g}$ ww (El Nabawi et al., 1987; Abd-Allah, 1992; AbdAllah and Ali, 1994), which is considerably less than the acceptable tolerance levels for human consumption. HCB levels were quantified in edible tissues from seven marine species from the Gulf of Naples in the southern Tyrrhenian Sea (Italy). The concentrations of HCB ranked from not detectable to $150.60 \mathrm{ng} / \mathrm{g}$ of fat weight in the samples analyzed (Ferrante et al., 2007). On the other hand, concentrations of various POPs (including HCB) were determined in tissue of marine benthic invertebrates in Spain (Deudero et al., 2007). The results obtained for $\mathrm{HCB}$ showed a narrow range of concentrations between 0.1 and $1.1 \mathrm{ng} / \mathrm{g}$ of wet weight.

Our estimations of trifluralin in fish samples revealed a detectable residue level in both cat fish and tilapia. But trifluralin only was detected in cat fish in area 2 with higher levels in cat fish than tilapia. Similarly, US.EPA, (1996) indicate that uptake of trifluralin bound to sediment by aquatic animals (especially animals which inhabit sediment) is likely to occur. The latter may result from oral uptake of sediment particles carrying trifluralin on their surface or by uptake of trifluralin dissolving from the sediment particles over the gills (EUTTF, 2002). Available data indicate that trifluralin can accumulate to detectable levels reach to $0.290 \mu \mathrm{g} / \mathrm{g}$ in fish and benthic invertebrates (US.EPA, 1996) and is stronger accumulated by sediment living aquatic organisms as cat fish and carp than by organisms living in the water body (US.EPA, 2009). Information on elimination rates indicates that the elimination rate of trifluralin in terrestrial animals might be significantly higher than in aquatic animals. No available data for trifluralin in fish species in Egypt, while there were few studies related to the soil and vegetables mentioned the detection of trifluraline residues in them (Mostafa et al., 1982).

\section{CONCLUSION}

The results of this study indicated the presence of some types of OPs, OCs, PCBs congeners, HCB and trifluralin pesticides in Elwasta and Mankbad, Assiut city, Egypt to varying degrees. A general trend from the results indicates an increase in pesticides residue levels in the area 2 (Mankbad) than area 1 (Elwasta). In addition, higher values were realized for the detected pesticide residues in cat fish than tilapia in this study. This gives a clear trend of the extent of chemical contamination in these areas. The surprising event in this study is the high values which realized 
for the OPs with respect to each type of fish or to the area investigated. These results suggested that the extensive use of these types of pesticides in the present time in which they rapidly deteriorated and not persist for long time in the environment, indicating the recent and huge use in the investigated areas. Moreover, this study, in our knowledge, is the first Egyptian study could detected the herbicide triflurin in fish tissues These pesticides and their derivatives have been banned in most parts of the world; however, the results of the study have shown that they are still being used in Egypt.

\section{REFERENCES}

Abd-Allah, A.M. (1992): Determination of DDTs and PCBs residues in Abu-Quir and El-Max Bays, Alexandria, Egypt. Toxicol Environ Chem; 36: 89-97.

Abd-Allah, A.M. and Ali, H.A. (1994): Residue levels of chlorinated hydrocarbons compounds in fish from El-Max Bay and Maryut Lake, Alexandria, Egypt. Toxicol Environ Chem; 42: 107-14.

Abd-Allah, A.M.; Hassan, I.M.; Naguib, M.M. and Abodonia, M.A. (1990): Survey of residues of organochlorine pesticides in some marketable Egyptian fish.J Assoc Off Anal Chem 1990; 73: 502-8.

Abd-Allah, A.M.; Ali, H.A. and El Sebae, A. (1998): Levels of chlorinated hydrocarbons in a teleost fish and a bivalve from the Egyptian Mediterranean coast and Nile estuary. Z Lebensm Unters Forsch A; 206: 25-8.

Abou-Donia, M.M. (1990): Specific device techniques for detecting fish contaminants. $\mathrm{Ph}$ $\mathrm{D}$ thesis in Agriculture Science, Faculty of Agriculture. Cairo: Ain Shams University.

AFSSA (Agence française de Sécurité Sanitaire des Aliments) (2007): Opinion of the 23rd October 2007 on the establishment of relevant maximum levels for non dioxin like polychlorobiphenyls in some foodstuffs, France. (http:// www.afssa.fr).

Aly, O.A. and Badawy, M.I. (1984): Organochlorine residues in fish from the River Nile, Egypt. Bull Environ Contam Toxicol; 33: 246- 52.

Arnich, N.; Tard, A.; Leblanc, J.; Le Bizec, B.; Narbonne, J. and Maximilien, R. (2009): Dietary intake of non-dioxin-like PCBs (NDLPCBs) in France, impact of maximum levels in some foodstuffs. Regul. Toxicol. Pharm; 54: 287-293.

Arnot, J.A. and Gobas, F.A. (2004): A food web bioaccumulation model for organic chemicals in aquatic ecosystems. Environ. Toxicol. Chem; 23: 2343-2355.

ATSDR (Agency for Toxic Substances and Disease Registry) (2002): Toxicological profile for DDD/DDT/DDE, US Department of Health and Human Services, PublicHealth Service, Atlanta, GA, USA.

Baars, A.J.; Bakker, M.I.; Baumann, R.A.; Boon, P.E.; Freijer, J.I.; Hoogenboom, L.A.P.; Hoogerbrugge, R.; van Klaveren, J.D.; Liem, A.K.D.; Traag, W.A. and de Vries, J. (2004): Dioxins, dioxin-like PCBs and non-dioxin-like PCBs in foodstuffs: occurrence and dietary intake in The Netherlands. Toxicol. Lett 2004; 151: 51-61.

Badawy, M.I. and El-Dib, M.A. (1984): Residues of organochlorine pesticides in fish from the Egyptian Delta Lakes. Environ Int; 10: 3-8.

Barber, J.L.; Sweetman, A.J.; Van Wijk, D. and Jones, K.C. (2005): Hexachlorobenzene in the global environment: emissions, levels, distribution, trends and processes. Sci. Total Environ; 349: 1-44.

Binelli, A. and Provini, A. (2003): DDT is still a problem in developed Countries: the heavy pollution of Lake Maggiore. Chemosphere; 52: 717-723.

Botaro, D.; Torres, J.P.M.; Malma, O.; Rebelo, M.F.; Henkelmann, B. and Schramm, K.W. (2011): Organochlorine pesticides residues in feed and muscle of farmed Nile tilapia from Brazilian fish farms. Food Chem. Toxicol; 49: 2125-2130.

Chen, S.; Yu, X.; He, X.; Xie, D.; Fan, Y. and Peng, J. (2009): Simplified pesticide multiresidues analysis in fish by low-temperature cleanup and solid-phase extraction coupled with gas chromatography/mass spectrometry. Food Chemist; 113(4): 1297-1300.

D'Amato, C.; Torres, J.P.M. and Malm, O. (2007): Determinação de DDT encontradas em peixes comestíveis de diferentes áreas da Amazônia brasileira. Oecologia Brasiliensis; 11 (2): 202-212.

Darko, G.; Akoto, O. and Oppong, C. (2008): Persistent organochlorine pesticide residues in fish, sediments and water from Lake Bosomtwi, Ghana. Chemosphere; 72: 21-24.

Deudero, S.; Box, A.; March, D.; Valencia, J.M. Grau, A.M. (2007): Organic compounds temporal trends at some invertebrate species from the Balearics, Western Mediterranean. Chemosphere; 1650: 86-90

Dogheim, S.M.; Almaz, M.M.; Kostandi, S.N. and Hegazy, M.E. (1988): Pesticide residues in milk and fish samples collected from Upper Egypt. J. Assoc Off Anal Chem; 71:872- 4.

Dogheim, S.M.; Nasr, E.N.; Almaz, M.M and El Tohamy, M.M. (1990): Pesticide residues in milk and fish samples collected from two Egyptian governorates. J. Assoc Off Anal Chem; 73: $19-21$.

Dogheim, S.M.; Gad Alla, S.A.; El Syes, S.M.; Almaz, M.M. and Salama, E.Y. (1996): Organochlorine and organophosphorus 
pesticide residues in food from Egyptian local markets. J Assoc Off Anal Chem; 79: 949-52.

Eaton, H.J. and Lydy, M.J. (2000): Assessment of water quality in wichita, kansas, using an index of biotic integrity and analysis of bed sediment and fish tissue for organochlorine insecticides. Archives of Environ Contam and Toxicol 39: 531-540.

EC 199/2006, (2006): Commission regulation No $199 / 2006$ EC of 3 February amending Regulation No 466/2001 EC setting maximum levels for certain contaminants in foodstuffs as regards dioxins and dioxin-like PCBs, Official Journal of European Union, L 2006; 32: 34-38.

EFSA (European Food Safety Authority) (2005): Opinion of the scientific panel on contaminants in the food chain on a request from the commission related to the presence of non dioxin-like polychlorinated biphenyls (PCB) in feed and food, Adopted on 8 November 2005, The EFSA Journal; 284: 1-137.

El Nabawi, A.; Heinzow, B. and Kruse, H. (1987): Residue levels of organochlorine chemicals and polychlorinated biphenyls in fish from the Alexandria region, Egypt. Arch Environ. Contam. Toxicol; 16: 689-96.

El Nemr, A.; Said, T.O.; Khaled, El Sikaily, A. and Abd-Allah, A.M.A. (2003): Polychlorinated biphenyls and chlorinated pesticides in mussels collected from Egyptian Mediterranean coast. Bull. Environ. Contam. Toxicol; 71: 290-297.

Essumang, D.K.; Togoh, G.K. and Chokky, L. (2009): Pesticides residues in the water and fish (Lagoon Tilapia) samples from lagoons in Ghana. Bull. Chem. Soc. Ethiop; 23(1): 19-27.

EU (European Commission Regulation) (2011): No 310/2011 of 28 March 2011 amending Annexes II and III to Regulation (EC) No 396/2005 of the European Parliament and of the Council as regards maximum residue levels for aldicarb, bromopropylate, chlorfenvinphos, endosulfan, EPTC, ethion, fenthion, fomesafen, methabenzthiazuron, methidathion, simazine, tetradifon and triforine in or on certain products. Official Journal of the European Union L; 86/1 54: 1-51.

EU (European Union Triflurin Task Force) (2002): EU - Directive 91/414/EEC Annex IIA and IIIA Summaries of studies on trifluralin and representative formulations (Dossier).

Ferrante, M.C.; Cirillo, T.; Naso, B.; Clausi, M.T.; Lucisano, A. and Cocchieri, R.A. (2007): Polychlorinated biphenyls and organochlorine pesticides in seafood from the Gulf of Naples (Italy). J Food Prot; 706: 15-70.

Fleming, L.E.; Broad, K.; Clement, A.; Dewailly, E.; Elmir, S.; Knap, A.; Pomponi, S.A.; Smith, S.; Gabriele, H. and Walsh, P. (2006): Oceans and human health: emerging public health risk in the marine environment. Mar. Pollut. Bull; 53: 545-560.

Han, X.; Nabb, D.L.; Mingoia, R.T. Yang, C.H. (2007): "Determination of Xenobiotic Instrinsic Clearence in Freshly Isolated Hepatocytes from Rainbow Trout and Rat and its Application in Bioaccumulation Assessment،" Environ. Sci. Technol; (41): 3269 - 3276.

He, L.; Luo, X.; Xie, Wang, C.; Jiang, X. and Lu, K. (2009): Ionic liquid-based dispersive liquidliquid microextraction followed highperformance liquid chromatography for the determination of organophosphorus pesticides in water sample. Analytica Chimica Acta; 655: 52-59.

Hogsette, J.A.; Koehler, P.G. and Kaufman, P.E. (2006): Pesticide safety around animals. $<$ http://edis.ifas.ufl.edu/IG128>.

Holtan, P. (1998): Catfish, Channel Catfish Flathead Catfish, - Wisconsin Department of Natural Resource Bureau of Fisheries Management.

Hurst, P.; Alistair, H. and Nigel, D. (1991): The Pesticide Handbook, Journeyman Press: London.

IPCS/WHO (International Programme on Chemical Safety/World Health Organization) (2003): CICADS 55 (Concise International Chemical Assessment Document), Polychlorinated biphenyls: human health aspects, Geneva, Switzerland.

(http://www.inchem.org/documents/cicads/cica ds/cicad55.htm).

Jankovic, S., Curcic Jovanovic, M.; Radicevic, T. and Antonijevic, B. (2008): Levels of nondioxinlike PCBs in freshwater fish from the Danube. Toxicol. Lett; 180: S181.

Jankovic, S.; Curcic, M.; Radicevic, T.; Stefanovic, S.; Lenhardt, M.; Durgo, K. and Antonijevic, $B$. (2010): Non-dioxin-like PCBs in ten different fish species from the Danube river in Serbia. Environ. Monit. Assess; 10.1007/ S10661-010-1820-x.

Jiries, A.B.; Al Nasir, F.M. and Beese, F. (2002): Pesticide and heavy metals residue in wastewater, soil and plants in wastewater disposal site near Al-lajoun Valley, Karak/Jordan. Water, Air, Soil Pollut; 133: 97-107.

Kairu, J.K. (1999): Organochlorine pesticide and metal residues in a cichlid fish، Tilapia, Sarotherodon (=Tilapia) alcalicus grahami Boulenger from Lake Nakuru، Kenya. Int. J. Salt Lake Res; 8 (3): 253-266.

Lin, W.X. (2002): The compilation of residue limits standards for pesticides and veterinary drugs in foodstuffs in the world Dalian: Dalian Maritime University Press; 3-1288. 
Manirakiza, P.; Covaci, A.; Nizigiymana, L.; Ntakimazi, G. and Schepensa, P. (2002): Persistent chlorinated pesticides and polychlorinated biphenyls in selected fish species from Lake Tanganyika, Burundi, Africa. Environ. Pollut; 117: 447-455.

Miles, J.R.W.; Harris, C.R. and Moy, P. (1978): Insecticide residues in organic soil of the Holland March, Ontario, Canada 1972- 1975. J Econ. Entomology; 71: 97- 101.

Mostafa, I.Y.; Zayed, S.M.; Adam, Y.M. and Attaby, H.S. (1982): Investigations on trifluralin binding to soil and possible uptake of bound residues by plants. J Environ Sci Health B; 17(3): 265-75.

Mwevura, H.; Othman, C.O. and Mhehe, G.L. (2002): Organochlorine pesticide residues in sediments and biota from the coastal of Dar Es Salaam City, Tanzânia. Mar. Pollut. Bull; 45: 262-267.

Ntow, W.J.; Gijzen, H.J.; Kelderman, P. and Drechsel, P. (2006): Pest. Manage. Sci; 62: 356 .

Salah El-Dien, W.M. and Mahmoud, H.A. (2011): Survey on some Chemical Pollutant Residues in Catfish at Sharkia Governorate, Egypt. J. Amer Sci; 7 (1): 286 -293.

Salah El-Dien, W.M. and Nasr, I.N. (2004): study of some organochlorine, pyrethroids and organophosphorus pesticide residues in fresh water crayfish (procambarus clarkii). J. Egypt Vet. Med. Ass; 64: 41-51.

Sapozhnikova, Y.; Bawardi, O. and Schlenk, D. (2004): Pesticides and PCBs in sediments and fish from the Salton Sea, California USA. Chemosphere; 55: 797-809.

Sormo, E.G.; Larsen, H.J.S.; Johansen, G.M. and Skaare, J.U. (2009): Jens sen, BM. Immunotoxicity of Polychlorinated Biphenyls (PCB) in Free-Ranging Gra y Seal Pups with Special Emphasis on Dioxin-Like Congeners. J Toxicol Environ Health; 72: 266-276.

Storelli, M.M. (2008): Potential human health risks from metals $(\mathrm{Hg}, \mathrm{Cd}$, and $\mathrm{Pb})$ and polychlorinated biphenyls (PCBs) via seafood consumption: Estimation of target hazard quotients (THQs) and toxic equivalents (TEQs). Food Chem. Toxicol; 46 (8): 2782-2788.

Sun, X.; Zhu, F.; Xi, J.; Lu, T.; Liu, H.; Tong, Y. and Ouyang, G. (2011): Hollow fiber liquid-phase microextraction as clean-up step for the determination of organophosphorus pesticides residues in fish tissue by gas chromatography coupled with mass spectrometry. Marine Poll Bull; 63: 102-107.

UNEP (1992): Egyptian engineered wetlands. In: Keckes and Associates, editors. Environmental impact assessment report (PA Lane S).

US.EPA (U.S. Environmental Protection Agency) (1983): Guidance for the Registration of Pesticide Product Containing Chlorobenzilate as the Active Ingredient, Washington DC.

US.EPA (U.S. Environmental Protection Agency) (1991): Memorandum from the office of Pesticides and Toxic Substances to Office of Pesticide Programs Division Director, Washington DC.

US.EPA (U.S. Environmental Protection Agency) (1996): Registration Eligibility Decision (RED): Trifluralin. United States Environmental Protection Agency Office of Prevention, Pesticides and Toxic Substances (7508W) EPA 738-R-95-040; April.

US.EPA (U.S. Environmental Protection Agency) (2009): The National Study of Chemical Residues in Lake Fish Tissue"; EPA-823-R-09-006; U.S. Environmental Protection Agency, Office of Water; Washington, DC.

US.FDA (Food and Drug Administration) (2001): Fish and fisheries products hazards and controls guidance, third ed. Rockville, M.D.: Center for Food Safety and Applied Nutrition, US FDA, USA.

US.FDA (Food and Drug Administration) (2007): Action Levels, Tolerances and Guidance levels for Poisonous or Deleterious Substances in Seafood. NSSP Guidance Documents Chapter II. Growing Areas: 04 Action; 279-547. http:/www.cfsan.fda.gov/ ear/nss4-42d.html

WHO (World Health Organization) (1999): Basic Food Safety for Health Workers, Geneva. $<$ http://www.who.int/foodsafety/publications/c apacity/healthworkes/en/index.html>.

Yamashita, N.; Urushigawa, Y.; Masunaga, S.; Walash, M. and Miyazaki, A. (2000): Organochlorine pesticides in water; sediment and fish from the Nile River and Manzala Lake in Egypt. Int $\mathrm{J}$ Environ Anal Chem 77: 289- 303. 


\section{بقايا المبيدات المتعددة في البلطي النيلي وسمك القرموط في مدينة أسيوط ، مصر ضحي يحي احد ، إيمان عز الدولة الشرقاوي}

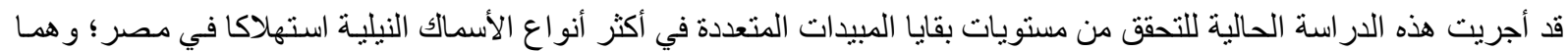

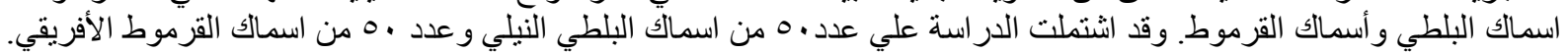

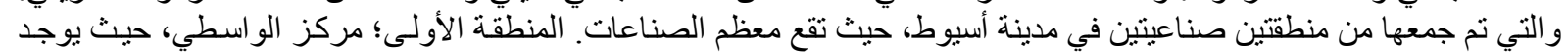

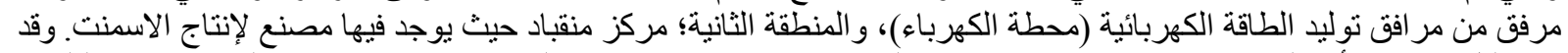

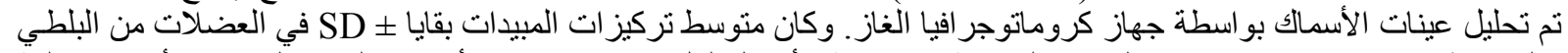

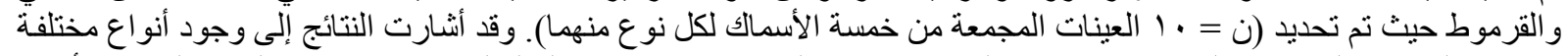

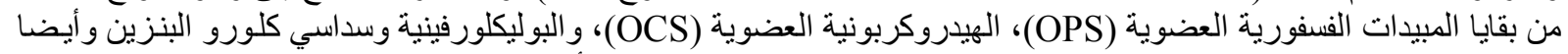

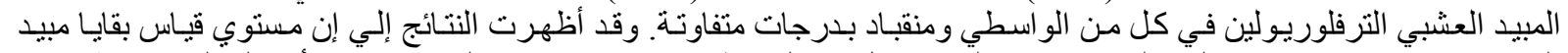

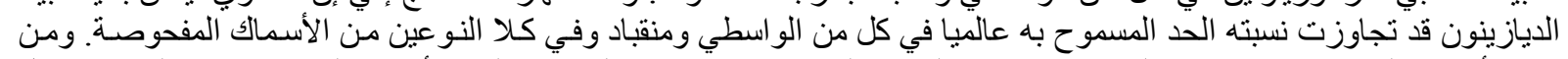

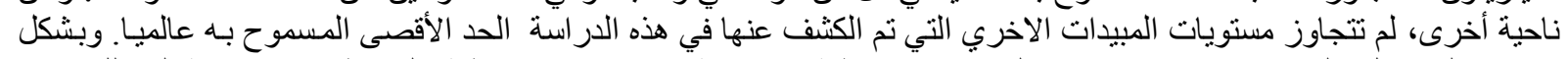

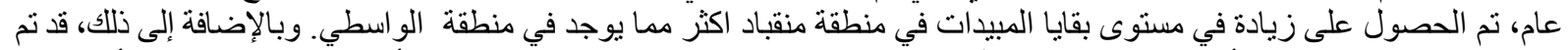

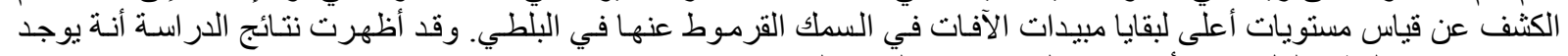
استخدام واسع النطاق لكل هذه الأنو اع من المبيدات في الوقت الحاض الحاضر في مصر. 